\section{Referendum on Massachusetts nuclear power}

\section{Boston}

THE future of nuclear power in Massachusetts will be determined in November by a state ballot on a measure that would permanently close the state's two nuclear power plants. If the measure is passed, Massachusetts would become the first state to outlaw commercial nuclear power for the generation of electricity.

Proponents of the nuclear shutdown have capitalized on the woes of the state's Pilgrim nuclear reactor to drive home their message. The Pilgrim plant has been shut for over two years because of safety violations, and is rated by the Nuclear Regulatory Commission as one of the least safe and worst-run nuclear plants in the country. They also note that Yankee Rowe in western Massachusetts, the state's only other nuclear power plant, is the oldest reactor in the United States and lacks the concrete containment shell found in newer reactors.

Opponents of the measure have stressed the economic costs of an abrupt shutdown of nuclear power production in the state, both in replacement energy from imported fossil fuels and in compensation to the plant's owners. Opponents of the shutdown have also noted their objection to what some call the "scare tactics" used by the measure's supporters in their depiction of the potential dangers of nuclear power. The group has organized an impressive collection of scientists and engineers, including several Nobel laureates and university presidents, to plead the case of the opposition in public forums and on television commercials.

The most recent polls indicate that the measure may lack the majority of voters needed to carry it, but observers say that the race will be a close one. A similar measure in Sacramento, California, seeking to close the Rancho Seco nuclear plant last June, lost by only 2,200 votes less than one per cent of the vote. Local utilities have raised a staggering $\$ 7.3$ million to fight the measure, more than twenty times the amount raised by the bill's supporters.

Kent Hansen, professor of nuclear engineering and associate director of the Energy Laboratory at Massachusetts Institute of Technology, is a vocal opponent of the shutdown. He does not see the measure as a solution to the state's energy problems and is frustrated by what he feels are "misleading" statements made by the measure's supporters. "I would hate to see a decision about what we want to do about nuclear power be based on misinformation", he says. Seth Shulman

\title{
New TV statellite is launched but will anyone watch?
}

Paris

THE French direct-broadcast television satellite, TDF-1, which was launched successfully on 28 October by an Ariane 2 rocket, puts an end to a ten-year telecommunications squabble. But with only two subscribers for its five channels, it may end up an expensive white elephant.

TDF-1 was conceived in 1977 as the means by which France - and Europe as a whole - could keep pace in the international television market in the face of overwhelming dominance by Japan. The satellite will be able to transmit highdefinition television (HDTV) pictures with digital stereo sound to homes throughout most of Western Europe, provided they have access to the right kind of parabolic antenna. The new broadcast standard, known as D2 Mac Packet, which TDF-1 uses, was finally adopted at a meeting in Dubrovnik in May 1986 in order to give Europe a single norm. At present, French televisions use the SECAM norm, while much of Europe has opted for PAL. Japan and the United States use a totally different standard, called NTSC. This chaotic incompatibility has proved a headache for manufacturers.

Ever since the West German and French governments agreed in 1979 to build the same satellite, the career of TDF-1 from drawing-board to geostationary orbit has been fraught with difficulties. In 1984, the director of the French telecommunications network (DGT), Gérard Théry, pronounced TDF-1 already out of date. DGT wanted its own, more modern satellite, Telecom 1, to be adopted instead. But the largely Franco-German consortium, Eurosatellite, which built TDF-1 and its West German sister, TVSAT1, has managed to persuade successive governments to back its project, despite a doubling of costs to around FF1800 million ( $\$ 290$ million) in ten years.

In May 1986 Eurosatellite was set back when a third-stage rocket motor failure halted Ariane launches until November last year. A cheaper, 17-channel satellite, ASTRA, being built by Luxembourg (due for launch next month) had meanwhile come on the scene, and TVSAT1 failed when its solar panels failed to open despite a perfect launch at the end of last year. Originally scheduled for March, the TDF1 launch was put back after Jacques Chirac offered to India the satellite's earlier place aboard an Ariane rocket.

Now that TDF-1 is finally in orbit, the question of who will use it remains. So far, only the West German Bundespost and a new seventh French channel, La SEPT, have signed contracts. With subscriptions to the French cable network disappointingly low - only 50,000 subscribers for the million homes so far equipped with cable - all the other French television stations have declined to take up FF40 million-a-year. But the French hope to launch TDF-2 in September 1989, if a FF1000 million shortfall can be made up from the private sector, while West Germany has booked space on Ariane in February 1990 for its TVSAT2.

Peter Coles

\section{Boston}

HARVARD University last week lost its appeal to overturn a plebiscite that would allow the nearly 4,000 clerical and technical workers at the university to join a union. An administrative law judge handed down a 40-page ruling that dismissed each of Harvard's claims that the election was held improperly.

The decision is a resounding victory for the union, an affiliate of AFSCME (American Federation of State, County and Municipal Employees) in a long and often bitter labour dispute with the university (see Nature 335,$389 ; 1988$ ). The contest has been watched closely by labour leaders around the nation. AFSCME officials have gone so far as to call the election a "test case" for the labour movement in the United States.

In the recent ruling, the judge not only dismissed Harvard's claims, but labelled some of their challenges "frivolous". The judge wrote that to his knowledge no case had ever been brought claiming misconduct while presenting evidence "devoid of coercion, misstatements, bribery, violence, or vandalism". In response to Harvard's contention that election-day processes had effectively denied some 1,700 members of the electorate equal access to the polls, the judge quoted from an earlier ruling stating "puffs of this sort of smoke do not indicate the existence of any flame".

The university now has a fortnight to appeal against the ruling. But because of the forcefulness of the decision, union supporters say they will press Harvard to accept and to give up what many now see as a hopeless effort to block union certification.

University officials say they are currently in the process of "reviewing the decision in depth" and have not decided whether to seek an appeal on the ruling.

Seth Shulman 